\title{
Upaya Mereduksi Prokrastinasi Akademik Pada Tugas Matematika Selama Pandemi Covid-19 Melalui Strategi Self Regulated Learning
}

\author{
${ }^{1}$ Althif Afandy, ${ }^{2}$ Fuat \\ Program Studi Pendidikan Matematika, Fakultas Pedagogi dan Psikologi, \\ Universitas PGRI Wiranegara Kota Pasuruan \\ Jl. Ki Hajar Dewantara No. 27-29 Pasuruan, Indonesia \\ Email: 1'afandyalthif7@gmail.com, ${ }^{2}$ boozfuat@gmail.com
}

\begin{tabular}{l}
\hline Tersedia Online di \\
http://www.jurnal.unublitar.ac.id/ \\
index.php/briliant
\end{tabular}

Sejarah Artikel

Diterima pada Februari 2021

Disetuji pada Mei 2021

Dipublikasikan pada Mei 2021

Hal. 398-409

\section{Kata Kunci:}

Prokrastinasi akademik; tugas harian matematika; self regulated learning

\section{DOI:}

http://dx.doi.org/10.28926/brilian t.v3i4.632

\begin{abstract}
Abstrak: Permasalahan yang dihadapi guru pada siswa kelas IX B SMPN 2 Pasuruan adalah sikap menunda-nunda dalam pengerjaan tugas. Penelitian dilakukan selama 2 hari dalam 2 minggu sesuai jadwal matematika angkatan 2020/2021. Penelitian tindakan kelas ini menggunakan metode Pretest \& Postest Design. Sampel diambil acak sebanyak 6 dari 30 siswa sebagai subjek penelitian. Pengumpulan data menggunakan The Academic Procrastination State Inventory (APSI). Hasil pretest menunjukan prokrastinasi akademik siswa tergolong tinggi, sebesar 81,17\%. Setelah diterapkan SRL, prokrastinasi turun menjadi 64\%, masih tinggi. Kemudian dilanjutkan tahap kedua, turun menjadi 39\%. Disimpulkan bahwa SRL dapat menurunkan prokrastinasi akademik secara signifikan apabila diberikan secara bertahap.
\end{abstract}

\section{PENDAHULUAN}

Hampir satu tahun Covid-19 menjadi pandemi yang menyebabkan munculnya kebijakan physical distancing. Muncul kebijakan new normal yang menghimbau masyarakat untuk bekerja, belajar, dan beribadah secara normal seperti pada umumnya tetapi harus tetap mematuhi protokol kesehatan. Bagi siswa tetap melaksanakan pembelajaran secara daring sebagai upaya memutus penyebaran Covid-19.

Pembelajaran pada masa pandemi dilakukan dengan menggunakan media online yang memanfaatkan gadget atau komputer. Bagi siswa, pembelajaran daring dapat menjadi kurang efektif dalam mengikutinya karena dikala pembelajaran daring berlangsung, siswa juga melakukan kegiatan lain yang bisa dilakukan bersama disamping kelas online sedang berlangsung. Akibatnya siswa tidak terlalu fokus dengan materi atau tugas yang diberikan oleh guru. Berdasarkan fakta dilapangan banyak siswa yang jarang diawasi orang tua saat mengikuti pembelajaran daring sehingga siswa cenderung menunda-nunda waktu belajar dan waktu pengerjaan tugas.

398 BRILIANT: Jurnal Riset dan Konseptual Volume 6 Nomor 2, Mei 2021 
Perbuatan menunda-nunda pengerjaan tugas yang dilakukan oleh siswa untuk dikerjakan dilain waktu dinamakan prokratinasi akademik (Fibrianti 2009). Beliau juga mengartikan prokrastinasi sebagai kecenderungan untuk menundanunda suatu tugas atau pekerjaan yang dilakukan secara sengaja dan berulangulang. Berdasarkan definisi tersebut jelas bahwa prokrastinasi dilakukan dengan sengaja yang artinya faktor-faktornya berasal dari keputusan diri sendiri. Noran (Akinsola, Tella et al. 2007), menganggap prokrastinator sebagai seseorang yang tahu apa yang ingin dilakukan, ia mencoba merencanakan untuk mengerjakan tugas tersebut, tetapi tidak berhasil menyelesaikannya. Berikut Ferrari (Putri 2013) juga mengatakan bahwa pelaku prokrastinator gagal dalam bidang akademik dikarenakan mereka menghindari pengerjaan tugas dan merasa takut apabila tugas tidak dapat mereka selesaikan. Banyak tugas yang diberikan dari guru dengan estimasi pengumpulan yang bervariatif. Mayoritas prokrastinasi akademik yang sering dilakukan oleh siswa yaitu saat memiliki tanggungan tugas yang berkenaan dengan logika atau abstrak termasuk didalamnya matematika. Hal ini sesuai dengan penelitian yang dilakukan oleh Rothblum (Solomon and Rothblum 1984) yang membagi area prokrastinasi menjadi enam area, salah satunya penundaan kinerja akademik secara umum (performing academic task in general) yang berarti melakukan penundaan pada seluruh tugas atau aktivitas yang berkaitan dengan akademik. Tugas harian matematika juga termasuk dalam aktivitas kinerja akademik siswa.

Menurut Kamus Besar Bahasa Indonesia (KBBI) Online, tugas yaitu pekerjaan yang menjadi tanggung jawab seseorang. Sedangkan tugas harian siswa dapat diartikan serangkaian pekerjaan yang menjadi tanggung jawab sebagai siswa di akademik yang diberikan dari guru dengan tujuan memenuhi standar nilai hasil belajar yang nantinya akan dilaporkan dalam bentuk laporan hasil belajar. Setiap mata pelajaran pasti berbeda tugas dan indikator yang harus dicapai siswa. Berkenaan dengan suatu pekerjaan yang membutuhkan perhitungan, konsep, rumus dasar acuan dan diberikan secara berkala dengan estimasi pengumpulan yang teratur dinamakan tugas harian matematika.

Penelitian sebelumnya yang dilakukan oleh Yuni (Aklima dkk., t.t.) mengupayakan untuk mengurangi prokrastinasi akademik siswa dengan layanan bimbingan kelompok di masa pandemi. Maka dari itu penelitian ini mencoba untuk memberikan strategi lain yang digunakan untuk mengurangi prokrastinasi akademik siswa khususnya pada mata pelajaran matematika di masa pandemi. Beberapa faktor yang mempengaruhi siswa melakukan prokrastinasi akademik tersebut diatas sehingga penelitian ini menggunakan strategi Self Regulated Learning. Menurut Alsa (Arjanggi \& Suprihatin, 2010), konsep ideal pembelajaran berdasar regulasi diri dengan cakupan mekanisme pengembangan diri dan pemantauan diri atas pikiran, perasaan dan perilaku dengan tujuan untuk mencapai sasaran yang dapat membantu mengatur waktu dan mengendalikan diri pada sistem pembelajarannya, yang dalam psikologi dinamakan Self Regulated Learning (SRL). Bandura (De Carvalho Filho and Yuzawa 2001), mendefinisikan SRL yaitu suatu keadaan dimana individu yang belajar sebagai pengendali aktivitas belajarnya sendiri, memonitor motivasi dan tujuan akademik, pengolah SDM dan benda, serta penentu dalam proses pengambilan keputusan dan pelaksana dalam proses belajar. 
Jurnal (Latipah 2015) juga menyebutkan bahwa proses-proses pengelolaan diri (self regulated process) yang mampu meningkatkan motivasi dalam pengelolaan diri belajar siswa meliputi efikasi diri, tujuan pribadi, nilai, dan atribusi. Menurut (Zimmerman 1989) Ghufron, (2011), pengelolaan diri mencakup tiga aspek yang dapat diaplikasikan dalam belajar, yaitu metakognitif, motivasi, dan perilaku. Dengan demikian disimpulkan bahwa SRL merupakan suatu proses dimana individu belajar secara aktif sebagai pengatur proses belajarnya sendiri dengan merencanakan, memantau, mengontrol, dan mengevaluasi secara mandiri. Dengan strategi SRL ini siswa diharapkan dapat menentukan tujuan belajarnya yang diinginkan karena dengan menetapkan tujuan belajarnya secara mandiri maka siswa dapat belajar untuk memonitor serta mengevaluasi cara belajarnya. Selain itu siswa juga mampu belajar self controlling untuk tetap teguh pada tujuan belajarnya serta memiliki daya kemandirian dalam belajar dan menentukan strategi yang sesuai dengan cara belajarnya sendiri. Oleh karena itu, SRL cocok sebagai strategi yang dapat menurunkan prokrastinasi akademik siswa.

Saat Covid-19 menjadi pandemi, jam pertemuan mata pelajaran mengikuti kebijakan pemerintah. Pihak lembaga sekolah juga diberi kewenangan tersendiri dalam menentukan jam tatap muka menyesuaikan dengan kondisi lingkungan dan kemampuan siswanya. Bertempat di SMP Negeri 2 Pasuruan, peneliti mendapat informasi bahwa setiap mata pelajaran memiliki satu kali tatap muka dengan alokasi waktu 2 jam pelajaran dalam satu minggu. Model yang dipakai yakni pembelajaran daring. Menurut Moore (Moore, Dickson-Deane et al. 2011) pembelajaran daring merupakan pembelajaran yang menggunakan jaringan internet dengan aksesbilitas, konektivitas, fleksibilitas, dan kemampuan untuk memunculkan berbagai jenis interaksi pembelajaran. Salah satu kekurangan pembelajaran daring (Pangondian, dkk., 2019) yaitu siswa yang tidak memiliki motivasi belajar yang tinggi maka rawan akan mengalami kegagalan. Siswa yang kurang termotivasi juga akan melakukan prokrastinasi karena karakteristik dan jenis tugas mempengaruhi seorang melakukan prokrastinasi. Seperti jenis tugas yang membutuhkan proses berpikir abstrak atau pemahaman konsep yang kebanyakan siswa kurang menyukainya. Hal yang mungkin terjadi adalah menghindar untuk mengerjakannnya, ini disebut dengan task aversiveness (Zakiyah, Hidayati et al. 2010). Penelitian yang dilakukan oleh Tunjung (Sriwigati, Widyastuti et al. 2020) di suatu sekolah jenjang SMA menunjukkan bahwa tingkat prokrastinasi akademik tergolong sangat tinggi. Hal ini membuktikan bahwa sebelum pandemi Covid-19, prokrastinasi akademik yang dilakukan oleh siswa sudah tergolong tinggi. Berbagai strategi telah dilakukan untuk menekan prokrastinasi akademik pada saat kondisi normal sebelum pandemi. Seperti yang dilakukan oleh Mufidah (Mufidah 2019) menunjukkan bahwa teknik SRL merupakan teknik paling efektif untuk mengurangi prokrastinasi akademik siswa. Berdasar hasil penelitiannya menyimpulkan bahwa terdapat hubungan saling mempengaruhi antara teknik SRL dengan prokrastinasi siswa yang dibuktikan dengan perbedaan yang signifikan antara hasil pretest dan posttest (taraf signifikasi sebesar 5\%). Oleh karena itu, SRL harus diterapkan dan dikembangkan dalam proses pembelajaran semua mata pelajaran, khususnya dalam mata pelajaran matematika untuk membentuk siswa yang disiplin waktu (Zhen dkk., 2016).

400 BRILIANT: Jurnal Riset dan Konseptual Volume 6 Nomor 2, Mei 2021 
Berdasar uraian diatas, peneliti tertarik untuk melakukan penelitian dengan judul "Upaya Mereduksi Prokrastinasi Akademik Siswa Pada Tugas Harian Matematika Selama Pandemi Covid-19 Melalui Strategi Self Regulated Learning". Adapun yang menjadi tujuan penelitian ini yaitu peneliti berupaya mengurangi prokrastiansi akademik siswa kelas IX B SMP Negeri 2 Kota Pasuruan pada saat diberi tugas matematika oleh guru dengan menerapkan strategi SRL saat pembelajaran daring selama pandemi Covid-19 ini.

\section{METODE}

Pendekatan yang digunakan adalah pendekatan kuantitatif. Pendekatan kuantitatif ditujukan untuk mengetahui perbedaan antara sebelum diberi perlakuan dan setelah diberi perlakuan. Jenis penelitian ini yaitu penelitian tindakan kelas. Penelitian Tindakan Kelas merupakan suatu pencermatan terhadap kegiatan belajar berupa sebuah tindakan nyata yang sengaja dimunculkan dan terjadi dalam sebuah kelas secara bersama (Komaidi and Wijayati 2011). Tindakan nyata yang dimaksud yaitu diterapkannya strategi SRL untuk mengurangi prokrastinasi akademik siswa. Populasi dalam penelitian ini yaitu siswa kelas IX B SMP Negeri 2 Kota Pasuruan Tahun Pelajaran 2020-2021 yang berjumlah 30 siswa. Sampel diambil sebanyak 6 siswa yang terdata sering terlambat dalam pengumpulan tugas matematika yang diberikan oleh guru selama pembelajaran daring. Waktu penelitian hari Sabtu pada minggu pertama tanggal 5 Desember 2020 dan hari Sabtu pada minggu kedua tanggal 12 Desember 2020. Dua hari itu guru matematika memberi PR berupa mengerjakan LKS bab transformasi geometri. Karena kebijakan pemerintah untuk selalu menjaga jarak dan menghindari kerumunan, maka peneliti langsung mengunjungi rumah siswa subjek penelitian. Berikut menjadi variabel bebas yaitu strategi SRL, sedangkan yang menjadi variabel terikat dalam penelitian ini yaitu pelaku prokrastinasi akademik. Peneliti menggunakan desain Pre Experimental yaitu Pretest \& Postest Design. Model PTK dalam penelitian ini menggunakan model Kemmis \& Taggart (Kemmis and Taggart 2002).

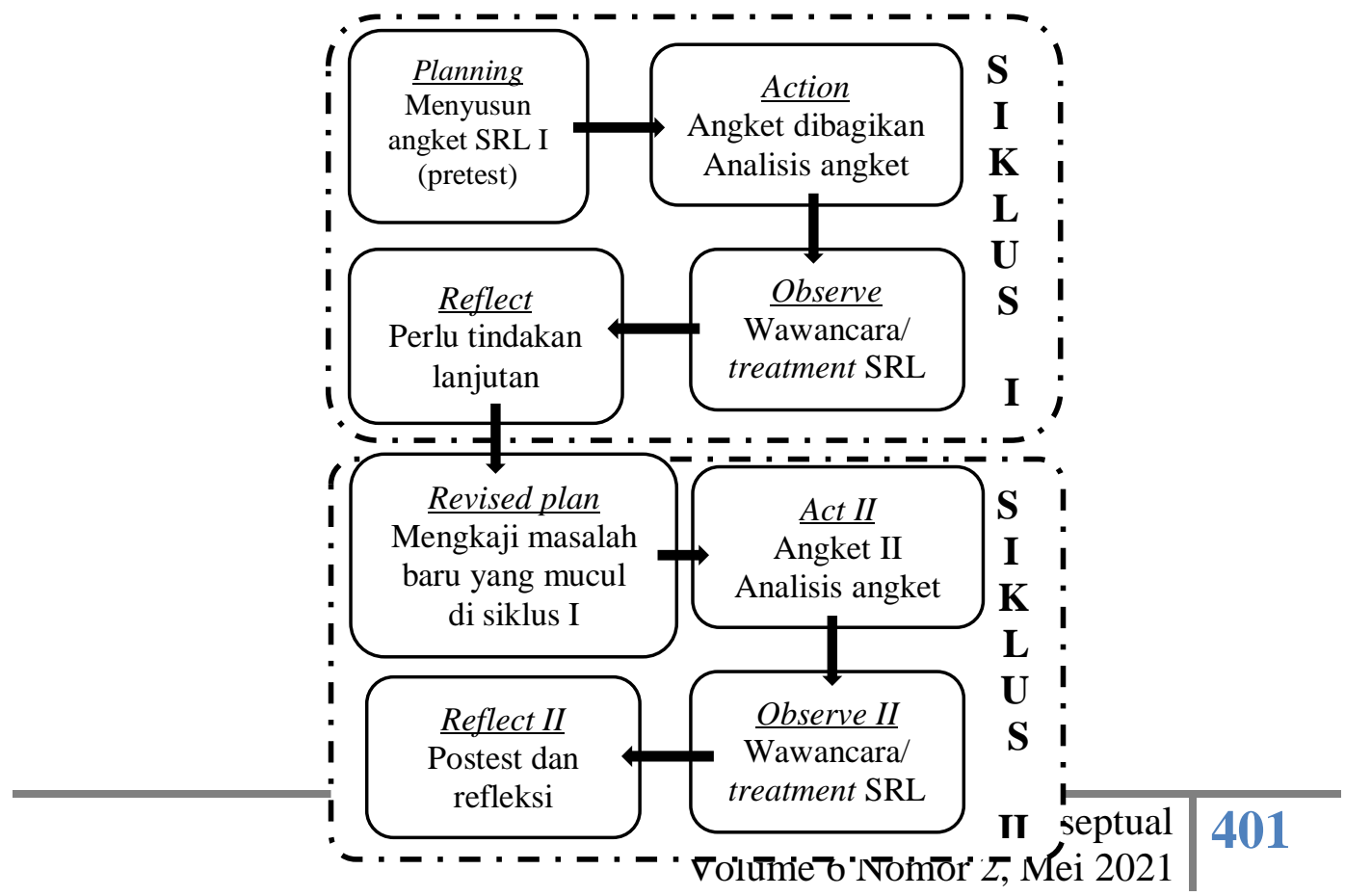


Gambar 1. Diagram alur penelitian Kemmis \& Taggart (2002)

Peneliti mengumpulkan data dengan metode wawancara langsung dari rumah ke rumah siswa prokrastinasi akademik. Pengumpulan data berupa angket berujuk pada e-book karya Henri C. Schouwenburg (Schouwenburg 1995), yang berjudul The Academic Procrastination State Inventory (APSI). Pretest dilakukan dengan memberikan angket prokrastinasi kepada siswa sebelum diberi tindakan. Angket kuisioner berisi 25 butir pernyataan dengan 4 indikator. Adapun analisis data yang dipakai yaitu deskriptif kuantitatif dan kualitatif. Analisis kuantitatif dengan membandingkan sebelum perlakuan dan sesudah perlakuan. Sedangkan analisis kualitatif yang digunakan adalah pengumpulan data deskriptif dengan wawancara tidak terstruktur. Pengkategorian prokrastinasi disajikan pada tabel berikut.

Tabel 1. Kelas Prokrastinasi (Schouwenburg, H. C. (1995))

\begin{tabular}{|c|c|}
\hline Rentang & Kategori \\
\hline$\leq \mathbf{4 5} \%$ & Rendah \\
\hline $\mathbf{4 6} \%-\mathbf{6 5} \%$ & Sedang \\
\hline $\mathbf{6 6} \% \mathbf{- 8 5} \%$ & Tinggi \\
\hline $\mathbf{8 6 6} \%$ & Sangat Tinggi \\
\hline
\end{tabular}

\section{HASIL DAN PEMBAHASAN}

Analisis data hasil angket bersumber pada The APSI. Dari 50 butir pernyataan dibagi menjadi 2 siklus yang masing-masing 25 penyataan dengan 4 indikator Sangat Setuju (SS), Setuju (S), Tidak Setuju (TS), dan Sangat Tidak Setuju (STS). Setiap pernyataan memiliki bobot prokrastinasi yang beragam.

Siswa prokrastinasi akademik menerima kedatangan peneliti untuk menjadikannya subjek penelitian dengan memberikan angket sebagai pengumpulan data hasil pretest.

Tabel 2. Hasil Pretest

\begin{tabular}{|c|c|c|c|}
\hline $\begin{array}{c}\text { Siswa } \\
\text { ke- }\end{array}$ & Kelas & Persentase & Kategori \\
\hline $\mathbf{1}$ & IX B & $83,33 \%$ & Tinggi \\
\hline $\mathbf{2}$ & IX B & $85 \%$ & Tinggi \\
\hline $\mathbf{3}$ & IX B & $66 \%$ & Tinggi \\
\hline $\mathbf{4}$ & IX B & $86,67 \%$ & Sangat Tinggi \\
\hline $\mathbf{5}$ & IX B & $76 \%$ & Tinggi \\
\hline $\mathbf{6}$ & IX B & $90 \%$ & Sangat Tinggi \\
\hline \multicolumn{2}{|c|}{ Rata-Rata } & $81,17 \%$ & Tinggi \\
\hline
\end{tabular}

Dari tabel diatas dapat dideskripsikan bahwa tingkat prokrastinasi akademik siswa masih tergolong tinggi sebelum diterapkan strategi SRL. Berikut masalah masing-masing siswa saat dilakukan wawancara.

402 BRILIANT: Jurnal Riset dan Konseptual Volume 6 Nomor 2, Mei 2021 
Tabel 3. Masalah yang Dihadapi

\begin{tabular}{|c|l|}
\hline $\begin{array}{c}\text { Siswa } \\
\text { ke- }\end{array}$ & \multicolumn{1}{|c|}{ Masalah } \\
\hline $\mathbf{1}$ & $\begin{array}{l}\text { Sinyal susah karena disini jauh dari } \\
\text { perkotaan, saat tugas datang harus ke jalan } \\
\text { raya dulu biar dapat diunduh, begitu juga } \\
\text { saat pengumpulan. }\end{array}$ \\
\hline $\mathbf{2}$ & $\begin{array}{l}\text { Tidak bisa memahami materi matematika } \\
\text { kalau tidak langsung tatap muka. }\end{array}$ \\
\hline $\mathbf{3}$ & $\begin{array}{l}\text { Sering menunda mengerjakan tugas } \\
\text { karena kalau saya mengerjakan tugas } \\
\text { menunggu mood sedang baik. }\end{array}$ \\
\hline $\mathbf{4}$ & $\begin{array}{l}\text { Jenuh dan bosan dengan pemberian materi } \\
\text { transformasi geometri lewat Edmodo, } \\
\text { materi sulit dipahami. }\end{array}$ \\
\hline $\mathbf{5}$ & $\begin{array}{l}\text { Kurang fokus mengerjakan soal } \\
\text { transformasi geometri karena lebih suka } \\
\text { menonton drama korea. }\end{array}$ \\
\hline $\mathbf{6}$ & $\begin{array}{l}\text { Malas mengerjakan tugas matematika, } \\
\text { sering tidak mengerjakan karena } \\
\text { jadwalnya di hari weekend, mending } \\
\text { ngegame aja. }\end{array}$ \\
\hline
\end{tabular}

Pemberian tindakan pertama ditujukan kepada siswa dengan persentase prokrastinasi akademik terendah dibawah rata-rata dari keenam siswa. Tindakan berupa wawancara tidak terstruktur dan treatment self regulated learning yang dilakukan antara peneliti dengan siswa secara face to face.

$P \quad$ : Situasi yang bagaimana sehingga mood Anda menjadi baik?

S3 : Mood baik saya ketika suasana tenang, tidak ada rasa kecewa dan penasaran sebelumnya, terasa damai meskipun tugas sekian banyak datang.

$P \quad$ : Tugas transformasi geometri tadi pagi apa sudah dikerjakan?

S3 : Belum. Karena pengumpulannya hari esok, maka saya mengerjakannya nanti sore. Lagipula waktu pengerjaan yang sangat dibatasi juga membuat saya tidak mood.

$P \quad$ : Semisal kalau nanti sore kedua adik Anda sedang bertengkar. Lantas apa Anda tetap menunda pengerjaan?

S3 : Ya, yang pasti menunggu suasana tidak berisik baru saya mulai mengerjakan.

$P \quad$ : Bagaimana kalau malam hari terjadi hal lain yang tak terduga seperti sore hari?

S3 : Ya entah. 
P : Nah. Sebaiknya Anda mengerjakan tugasnya langsung pada waktu setelah tugas diberikan dari guru. Meskipun kondisi kurang mood, setidaknya Anda sudah memulai mengerjakan. Nanti disela-sela mengerjakan Anda Kembali bad mood, maka bisa dilanjutkan setelah mood kembali baik. Tidak masalah tugas dicicil sedikit demi sedikit.

Pelaku S3 tidak terlalu mempedulikan model pembelajaran apa yang dipakai sehari-hari saat mata pelajaran matematika. Sedikit ada perbedaan dengan pelaku S2 yang kesulitan saat memahami materi matematika dikarenakan guru hanya memberi file materi lewat Edmodo tanpa menjelaskan secara detail langsung dari guru. Berbeda jauh dengan kebiasaan pelaku S6.

S6 : Saya tidak bisa mengerjakan tugas matematika karena bu guru selalu memberikan tugas saat weekend, sedangkan weekend rutin saya mabar dengan tim squad saya. Lagipula weekend juga seharusnya libur dari segala tugas sekolah.

$P \quad$ : Bagaimana kalau nilai matematika Anda tidak sesuai yang diharapkan?

S6 $\quad$ : Nanti saat mau PAS juga bakalan ditagih sama bu guru Siapa juga yang mau pusing mengerjakan tugas matematika saat weekend, yah mending ngegame saja.

$P \quad:$ Apa Anda tidak berpikiran bahwa teman squadmu sudah mengerjakan tugasnya?

S6 : Wah kalau itu mana saya tahu.

$P \quad$ : Coba ditanyakan sama mereka. Sebaiknya sebelum Anda menghibur diri, ajaklah teman squad Anda untuk menyelesaikan tugas terlebih dahulu, mungkin dari mereka ada yang belum mengerjakan tugasnya. Lebih lega, mabar tugas matematika dulu lalu mabar game.

Setiap siswa mempunyai masalah masing-masing yang dapat menyebabkan siswa tersebut melakukan prokrastinasi akademik. Mata pelajaran yang berhubungan dengan matematika, logika, abstrak juga turut meningkatkan prokrastinasi akademik karena mereka selalu berpikir lebih dalam pada saat mengerjakan tugas matematika, berbeda dengan tugas mata pelajaran lainnya (Setyowati dkk., t.t.). Peneliti memberikan angket yang kedua berisi 25 butir pernyataan. Data angket prokrastinasi hari kedua sebagai berikut.

Tabel 4. Hasil Pretest Hari Kedua

\begin{tabular}{|c|c|c|c|}
\hline $\begin{array}{c}\text { Siswa } \\
\text { ke- }\end{array}$ & Kelas & Persentase & Kategori \\
\hline $\mathbf{1}$ & IX B & $70 \%$ & Tinggi \\
\hline $\mathbf{2}$ & IX B & $64 \%$ & Sedang \\
\hline $\mathbf{3}$ & IX B & $45 \%$ & Rendah \\
\hline $\mathbf{4}$ & IX B & $74 \%$ & Tinggi \\
\hline $\mathbf{5}$ & IX B & $60 \%$ & Sedang \\
\hline $\mathbf{6}$ & IX B & $73 \%$ & Tinggi \\
\hline \multicolumn{2}{|l}{ Rata-Rata } & $64,33 \%$ & Tinggi \\
\hline
\end{tabular}

404 BRILIANT: Jurnal Riset dan Konseptual Volume 6 Nomor 2, Mei 2021 
Hasil angket hari kedua menujukkan tingkat prokrastinasi akademik masih tinggi. Muncul masalah baru setelah diberi tindakan SRL pada hari sebelumnya.

Tabel 5. Masalah Baru yang Dihadapi

\begin{tabular}{|c|l|}
\hline $\begin{array}{c}\text { Siswa } \\
\text { ke- }\end{array}$ & \multicolumn{1}{|c|}{ Masalah } \\
\hline $\mathbf{1}$ & $\begin{array}{l}\text { Saat jam pelajaran daring akan dimulai, } \\
\text { saya sudah siap standby di rumah orang } \\
\text { yang dipinggir jalan. Kalau cuaca sedang } \\
\text { hujan, berangkat ke situ menunggu hujan } \\
\text { sudah reda. }\end{array}$ \\
\hline $\mathbf{2}$ & $\begin{array}{l}\text { Kebetulan setiap hari Jumat malam ikut } \\
\text { rapat karang taruna, kalau biasanya } \\
\text { majelis yasinan dahulu, kadang masih saja } \\
\text { terlambat mengumpulkan tugasnya. }\end{array}$ \\
\hline $\mathbf{3}$ & $\begin{array}{l}\text { Sering mencicil tugas karena mood } \\
\text { ditengah mengerjakan selalu berubah, } \\
\text { akhirnya kadang ketiduran. Bangun sudah } \\
\text { lupa kalau ada tugas. } \\
\text { Tugas dikerjakan saat pagi hari sebelum } \\
\text { melakukan kegiatan lain. Tapi saat soalnya } \\
\text { terlalu sulit, akan saya skip karena saya } \\
\text { tidak paham materinya. }\end{array}$ \\
\hline $\mathbf{5}$ & $\begin{array}{l}\text { Masih suka ngerjakan tugas matematika } \\
\text { dengan nonton drakor, karena bisa } \\
\text { membantu meringankan pikiran, lebih } \\
\text { encer. }\end{array}$ \\
\hline $\mathbf{6}$ & $\begin{array}{l}\text { Saya lebih banyak malasnya daripada } \\
\text { rajinnya }\end{array}$ \\
\hline
\end{tabular}

Hal yang menarik di masalah baru kali ini adalah 4 dari 6 siswa telah mampu menyelesaikan tugas matematikanya secara tepat waktu meskipun pengerjaannya kurang maksimal.

$P \quad$ : Anda hebat bisa memanage waktu dengan baik meskipun dua kegiatan bisa berjalan dengan bergantian. Apa pengumpulan tugasnya tepat waktu?

S5 : Karena drakornya terlalu mendalami, akhirnya saya mengembalikan fokus agak susah, Pak. Tugas baru saya kumpulkan setengah jam dari dateline. Sering juga seperti ini.

$P \quad$ : Sebaiknya Anda fokus satu pekerjaan dulu, terutama mengerjakan tugasnya. Nanti setelah tugas matematikanya selesai, bisa untuk melanjutkan hobi Anda. Kan berasa lebih lega daripada dua-duanya berjalan beriringan. 
Siswa juga merasa kalau dirinya belum bisa menangkap materi matematika, karena yang diberikan hanya file materi saja tanpa penjelasan secara kontak langsung dengan guru.

S4 : Saya tidak bisa belajar lewat online seperti ini. Karena materi cuman diberi file pdf saja, tanpa dijelaskan ulang yang ini bagaimana, ini bagaimana, apalagi tugas matematika. Belajar matematika lewat media online lebih sulit memahaminya, mending tatap muka saja. Yang penting protokol kesehatan.

$P \quad:$ Coba cari temanmu sekelas yang mempunyai masalah sama seperti Anda. Anda bisa saling belajar bersama dengan dia agar meteri yang diberikan oleh guru bisa didiskusikan.

Siswa pelaku prokrastinasi S1, S2, S3, dan S5 telah berhasil mengumpulkan tugas tepat waktu sebelum batas waktu ditentukan. Ini menandakan tindakan SRL secara wawancara dan pemberian treatment telah berhasil. Untuk siswa lainnya sudah mulai membiasakan untuk tidak menunda-nunda dalam pengerjaan tugas matematika, meskipun itu sulit. Setelah semua tugas matematika telah dikumpulkan ke guru, meskipun ada yang masih terlambat. Peneliti memberi angket post-test untuk keenam siswa pelaku diatas. Hasil post-test sebagai berikut.

Tabel 6. Hasil Post-Test

\begin{tabular}{|c|c|c|c|}
\hline $\begin{array}{c}\text { Siswa } \\
\text { ke- }\end{array}$ & Kelas & Persentase & Kategori \\
\hline $\mathbf{1}$ & IX B & $45 \%$ & Rendah \\
\hline $\mathbf{2}$ & IX B & $37 \%$ & Rendah \\
\hline $\mathbf{3}$ & IX B & $26 \%$ & Rendah \\
\hline $\mathbf{4}$ & IX B & $46 \%$ & Sedang \\
\hline $\mathbf{5}$ & IX B & $41 \%$ & Rendah \\
\hline $\mathbf{6}$ & IX B & $40 \%$ & Rendah \\
\hline \multicolumn{2}{|l}{ Rata-Rata } & $39,167 \%$ & Rendah \\
\hline
\end{tabular}

Dari ketiga pengambilan data berupa angket prokrastinasi akademik, didapatkan adanya penurunan prokrastinasi akademik disetiap siklus. Ini menujukkan bahwa strategi SRL dapat mempengaruhi prokrastinasi akademik siswa. 


\section{DIAGRAM HASIL PEMBERIAN TINDAKAN SRL}

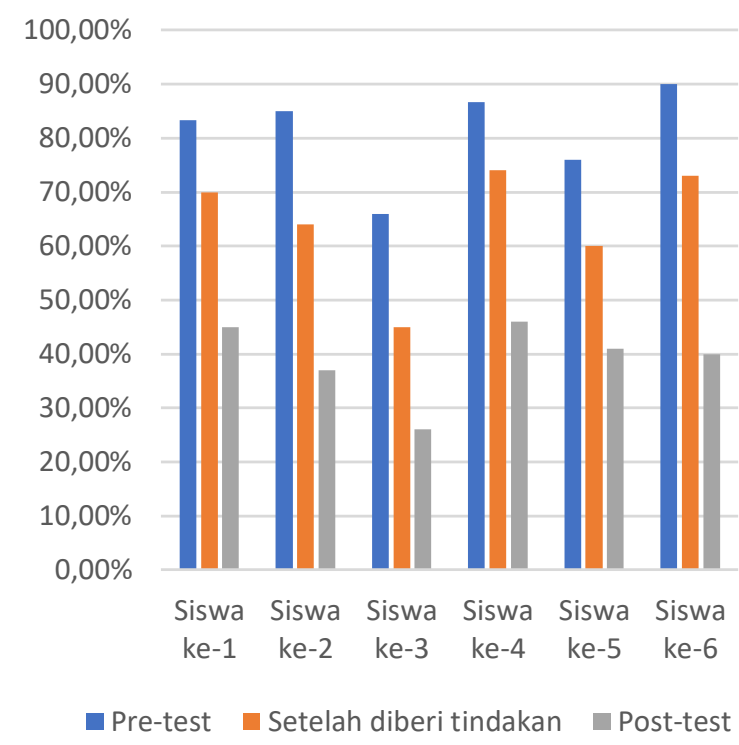

Gambar 2. Diagram Penurunan Prokrastinasi

\section{KESIMPULAN}

Berdasarkan hasil penelitian mengenai pemberian tindakan dengan strategi SRL pada siswa pelaku prokrastinasi akademik terhadap tugas harian matematika di kelas IX B SMP Negeri 2 Pasuruan diperoleh kesimpulan: dari sebelum pemberian tindakan SRL, prokrastinasi akademik 6 siswa dari 30 siswa tergolong sangat tinggi yakni menunjukkan rata-rata $81,17 \%$ dari angket prokrastinasi yang diisi oleh siswa. Diberikannya strategi SRL membuat prosentasenya menurun menjadi 64,33\%, masih tergolong tinggi. Peneliti berupaya menekan sampai tingkat prokrastinasi siswa benar-benar rendah, sehingga diperlukan tindakan SRL tahap kedua, mengalami penuruan signifikan sampai pada prosentase 39,167\%. Maka dapat disimpulkan bahwa pemberian tindakan SRL dapat menurunkan prokrastinasi akademik siswa terhadap tugas matematika yang diberikan, apabila dilakukan secara bertahap dan terjadwal, khususnya disaat pandemi Covid-19 ini yang mengharuskan siswa belajar dari rumah.

\section{SARAN}

Terima kasih penulis tujukan kepada siswa kelas IX B SMP Negeri 2 Pasuruan 2020/2021 sebagai subjek dari penelitian. Kepada Dr. Fuat, M. Pd. selaku pembimbing dalam penelitian penulis mengucapkan banyak terima kasih telah membimbing peneliti menyusun artikel ini. Penelitian tindakan ini kurang dalam hal heterogenitas sampel yang digunakan. Untuk peneliti selanjutnya diharapkan subjek penelitian dimulai dari jenjang SD sampai SMA. Karena beragamnya cara berpikir di jenjang tersebut. Hal itu wajar karena perkembangan kognitif pada setiap tahap usia berbeda menurut Piaget (Suparno 2001). Karateristik ras juga belum 
digunakan di penelitian ini. Penelitian yang dilakukan oleh Purdie (Purdie, Hattie et al. 1996) (1996) menjelaskan bahwa perbedaan budaya dan ras berdampak pada perbedaan penggunaan strategi SRL. Besar harapan peneliti selanjutnya untuk mempertimbangkan hal ini.

\section{DAFTAR RUJUKAN}

Akinsola, M. K., et al. (2007). "Correlates of academic procrastination and mathematics achievement of university undergraduate students." Eurasia Journal of Mathematics, science and technology education 3(4): 363-370.

Aklima, Y., Supriyanto, A., \& Antara, U. (t.t.). UPAYA MENGURANGI PROKRASTINASI AKADEMIK SISWA MELALUI LAYANAN BIMBINGAN KELOMPOK (PADA MASA PANDEMI COVID-19 DI SMA NEGERI 1 MUARA BATU). 9.

Arjanggi, R., \& Suprihatin, T. (2010). METODE PEMBELAJARAN TUTOR TEMAN SEBAYA MENINGKATKAN HASIL BELAJAR BERDASAR REGULASI-DIRI. Makara Human Behavior Studies in Asia, 14(2), 91. https://doi.org/10.7454/mssh.v14i2.666

De Carvalho Filho, M. K. and M. Yuzawa (2001). "The effects of social cues on confidence judgments mediated by knowledge and regulation of cognition." The Journal of Experimental Education 69(4): 325-343.

Fibrianti, I. D. (2009). Skripsi. Hubungan Antara Dukungan Sosial Orangtua Dengan Prokrastinasi Akademik Dalam Menyelesaikan Skripsi Pada Mahasiswa Fakultas Psikologi Universitas Diponegoro Semarang, Undip Semarang.

Fuat, F. (2018). KEGAGALAN BENTUK SKEMA ARGUMEN BUKTI. Jurnal Ilmiah Edukasi \& Sosial, 7(2), 146-150.

Kemmis, S. and M. Taggart (2002). "R. 1988." The action research planner.

Komaidi, D. and W. Wijayati (2011). "Panduan Lengkap Penelitian Tindakan Kelas." Yogyakarta: Sabda Media.

Latipah, E. (2015). "Strategi self regulated learning dan prestasi belajar: kajian meta analisis." Jurnal psikologi 37(1): 110-129.

Moore, J. L., et al. (2011). "e-Learning, online learning, and distance learning environments: Are they the same?" The Internet and Higher Education 14(2): 129-135.

Mufidah, U. N. (2019). EFEKTIVITAS TEKNIK SELF-REGULATED LEARNING UNTUK MEREDUKSI PROKRASTINASI AKADEMIK PESERTA DIDIK KELAS XI MA MIFTAHUL ULUM KOTA BARU LAMPUNG TENGAH TAHUN PELAJARAN 2019/2020, UIN Raden Intan Lampung.

Purdie, N., et al. (1996). "Student conceptions of learning and their use of selfregulated learning strategies: A cross-cultural comparison." Journal of educational psychology 88(1): 87.

Putri, P. W. (2013). Analisis Faktor Prokrastinasi Akademik: Studi pada Mahasiswa Psikologi Angkatan 2009 Universitas Islam Negeri Maulana Malik Ibrahim Malang, Universitas Islam Negeri Maulana Malik Ibrahim.

Schouwenburg, H. C. (1995). Academic procrastination. Procrastination and task avoidance, Springer: 71-96. 
Setyowati, E., Santosa, H., Biantoro, Y., \& Ma'arif, S. (t.t.). UPAYA MENURUNKAN PROKRASTINASI AKADEMIK MELALUI LAYANAN KONSELING KELOMPOK DENGAN PENDEKATAN BEHAVIORISTIK PADA PESERTA DIDIK KELAS XI TKJ DI SMK MA'ARIF 1 NANGGULAN. 9.

Solomon, L. J. and E. D. Rothblum (1984). "Academic procrastination: Frequency and cognitive-behavioral correlates." Journal of counseling psychology 31(4): 503.

Sriwigati, T., et al. (2020). "UPAYA MEREDUKSI PROKRASTINASI AKADEMIK MELALUI LAYANAN BIMBINGAN KELOMPOK TEKNIK DISKUSI BAGI PESERTA DIDIK KELAS XII APHP B SMK NEGERI 1 WANAYASA."

Suparno, P. (2001). Teori perkembangan kognitif jean piaget, Kanisius.

Tugas (Def. 1) (n.d). Dalam Kamus Besar Bahasa Indonesia (KBBI) Online. Diakses melalui https://kbbi.web.id/tugas, 15 Desember 2020.

Zakiyah, N., et al. (2010). "Hubungan antara penyesuaian diri dengan prokrastinasi akademik siswa sekolah berasrama SMP N 3 Peterongan Jombang." Jurnal Psikologi Undip 8(2).

Zhen, B., Weber, K., \& Mejia-Ramos, J. P. (2016). Mathematics Majors' Perceptions of the Admissibility of Graphical Inferences in Proofs. International Journal of Research in Undergraduate Mathematics Education, 2(1), 1-29. https://doi.org/10.1007/s40753-015-0010-1

Zimmerman, B. J. (1989). "A social cognitive view of self-regulated academic learning." Journal of educational psychology 81(3): 329. 